\title{
Legacy of mercury pollution
}

SIR - From about 1570, South and Central America established a hegemony on the silver market which lasted for more than 300 years ${ }^{1,2}$. The primary impetus for the massive silver output was the introduction of a cheap and simple technology - the patio or mercury amalgamation - into silver production which was ideally suited for the low-grade ores (as low as $0.4 \mathrm{~kg}$ per tonne of ore) and some unique ore minerals (such as argentite and cerurgyrite) common in the region. Although the patio process supplied the silver that sustained the European economy, it also left an unparalleled legacy of massive mercury pollution.

Although the principle of amalgamation had been known and used since ancient times ${ }^{3}$, its development into an industrialscale operation was first made in New Spain (now Mexico) in 1554 by Bartolome de Medina ${ }^{1,2}$. Even as late as 1870 , about $70 \%$ of all the Mexican silver was still being produced by this process ${ }^{2}$. Although it was supplanted by the 'barrel amalgamation' or Born process in the late nineteenth century, the technological nexus between silver and mercury was not severed until cyanide amalgamation was introduced around 1900 (see ref. 2).

Virtually all the mercury used in Spanish America came from three sources, in order of volume being Almaden in southern Spain, Huancavelica in central Peru and Idria in modern Slovenia ${ }^{3-5}$. Although some of the mercury used to extract the silver was recovered, a large fraction was generally wasted in the process because of the crude equipment and conditions. Until the middle of the eighteenth century, around $1.5 \mathrm{~kg}$ of mercury was lost for every $\mathrm{kg}$ of silver produced $^{2,4}$. The ratio (or correspondencia), however, could be as low as $0.85 \mathrm{~kg}$ $\mathrm{Hg}$ per $\mathrm{kg} \mathrm{Ag}$ for impoverished ores and as high as $4.1 \mathrm{~kg} \mathrm{Hg}$ per $\mathrm{kg} \mathrm{Ag}$ for very rich ores ${ }^{3-5}$. Because of depressed mercury prices during $1760-1810$, the loss of 2.4-2.9 $\mathrm{kg} \mathrm{Hg}$ per $\mathrm{kg} \mathrm{Ag}$ produced became common in many mining districts $^{6}$. The correspondencia for the colonial silver mines were quite similar to the current loss of mercury associated with gold extraction in the Amazon of Brazil, typically $1.3-1.7 \mathrm{~kg}$ per $\mathrm{kg}$ of gold recovered $^{6,7}$.

Because nearly all the mercury produced in Almaden and Huancavelica went to the silver refineries in Spanish America, I have estimated the annual loss of mercury (see figure) using the outputs from these two sources and the recorded imports from the Idria mines ${ }^{2-5}$ since the discovery of the Huancavelica mercury deposits in 1563. Between 1580 and 1820 , the calculated losses varied from 292 to 1,085 tonnes per yr, with an average of 527. By comparison, the input of mercury into the Amazon associated with the current gold rush is $90-120$ tonnes per yr (ref. 6). The cumulative loss of mercury in South America between 1570 and 1820 was about 126,000 tonnes (see figure).

About 99,400 tonnes of silver were produced in South and Central America

$65 \%$ ) would have been released to the atmosphere during the burning of the mercury amalgam, the amalgamation process on the open patio floor or in heated cauldrons, and the squeezing of the pella (amalgam) to remove the excess mercury. The fraction estimated to be emitted to the atmosphere in colonial times is comparable to the $65-83 \%$ for current recovery of gold in the Amazon 6,7 .

Using these data, the atmospheric fluxes of mercury from the silver mining in colonial South America during 15871820 would have been $180-705$ tonnes per yr. Because the anthropogenic sources of the period released much less than the total $910-6,200$ tonnes $\mathrm{Hg}$ emitted annually by modern industries ${ }^{10}$, it is clear that the silver mines were the dominant source of atmospheric mercury pollution. The importance of this source of mercury pollution has not been considered in previous discussions of the global and regional cycling of mercury ${ }^{11}$. Under the hot tropical conditions especially of Mexico, any mercury in the abandoned mine wastes or deposited in the aquatic sediments remains liable to be methylated and released to the atmosphere ${ }^{12}$. And any deposited mercury can subsequently become mobilized and could cycle in the atmosphere for a long time. It is there-

between 1820 and 1900 (refs 8, 9). Assuming the ratio of mercury lost to silver produced to be $1: 1$ (less than the ratios in colonial times) and that $70 \%$ of the silver was recovered by the patio process and its modifications, the cumulative discharge of mercury during the 80 years is about 70,000 tonnes. From the total figure, the average discharge rate in post-independence times is estimated to be 875 tonnes per yr. Thus, for $1570-1900$, when the patio process was in common use, the total discharge of mercury from silver mining in South and Central America was around 196,000 tonnes.

Although mercury was used in numerous silver mines, the most sustained losses occurred in only a few major silver-mining regions 5 . What happened to the unprecedented quantities of mercury discharged? The old Spanish literature is virtually silent on the ecological and human health effects of what would have been severe mercury pollution. Around $10 \%$ of the mercury supply would have been lost during transport and storage 1,2 and about $25-30 \%$ of the silver (and implicitly the mercury as well) would have been left behind in the residue or removed in waste streams ${ }^{2}$. The balance of the mercury used (60- fore possible that the Spanish American silver mines were partly responsible for the high background concentrations of mercury in the global environment now being reported.

Jerome 0 . Nriagu

Environment Canada,

National Water Research Institute,

Box 5050, Burlington,

Ontario L7R 4A6,

Canada

1. Prieto, C. Mining in the New World (McGraw-Hill, New York, 1973).

2. Brading, D. A. \& Cross, H. E. Hispanic Am. Hist. Rev. 52, 547-579 (1972).

3. Blanchard, I. Russia's Age of Silver (Routledge, London, 1989).

4. Fisher, J. R. Silver Mines and Silver Miners in Colonial Peru, 1776-1824 (Centre for Latin American Studies, Univ. Liverpool, 1977)

5. Bethell, L. (ed.) in The Cambridge History of Latin America 105-151 (Cambridge Univ. Press, 1984)

6. Pfeiffer, W. C. et al. Sci. tot. Envir. 87, 233-240 (1989).

7. Lacerda, L. D. \& Salomons, W. Mercury in the Amazon (Dutch Ministry of Housing, Physical Planning \& Environment Report, Inst. of Soil Fertility, Haren, 1991).

8. Mohide, T. P. Silver (Ontario Mineral Policy Background Paper No. 20, Ministry of Natural Resources, Toronto, 1985).

9. Cronshaw, H. B. Silver Ores (Murray, London, 1921)

10. Nriagu, J. 0. \& Pacyna, J. M. Nature 333, 134-139 (1988).

11. Andren, A. W. \& Nriagu, J. O. in Biogeochemistry of Mercury in the Environment (ed. Nriagu, J. 0.) 1-21 (Elsevier, Amsterdam, 1979).

12. Lindberg, S. E. \& Turner, R. R. Nature 268, 133-136 (1977). 